\title{
Role of notch pathway and HNF1 in cell death induced by HDACs inhibitors in ovarian cancer cell lines, serous and clear cells
}

\author{
Fernanda Silva ${ }^{1 *}$, Jacinta Serpa ${ }^{1,2+}$, Germana Domingues ${ }^{2}$, Gabriela Silva², António Almeida ${ }^{2,3}$, Ana Félix ${ }^{1,4}$ \\ From 16th International Charles Heidelberger Symposium on Cancer Research \\ Coimbra, Portugal. 26-28 September 2010
}

Ovarian cancer is the leading cause of death from gynaecological. There is an urgent need for testing novel tumour markers and therapeutic agents. HDAC inhibitors are a new class of target anticancer agents, which block deacetylation function, causing cell cycle arrest, differentiation and/or apoptosis. Vorinostat is an inhibitor of class I and II HDACs. Butyric acid is a small molecular weight carboxylates that are class I HDAC inhibitors. Our objective was to evaluate cell and molecular alterations induced by HDACs inhibitors in ovarian cancer cells. For that, we exposed serous ovarian carcinoma cell lines, ES2 and OVCAR3, and clear cells carcinoma cell line, OV90, to butyric acid and to vorinostat. Cell death, apoptosis and necrosis, was evaluated by FACS using Annexin V and 7AAD staining. By RQ-PCR we evaluated the expression of Notch downstream target genes, the expression of TP53 and HNF1, which is responsible for the clear cells carcinoma morphological phenotype. We observed that butyric acid is more effective as an inducer of cell death than vorinostat, in all cell lines. However, apoptotic levels induced by vorinostat are higher in OV90 cells than in ES2 and OVCAR3. We also observed that Notch pathway is activated in all ovarian cell lines by butyric acid, since Notch downstream targets HES1, HEY1 and 2 are more expressed. P53 expression is slightly decreased in all cell lines after exposure to butyric acid. Interestingly, HNF1 expression decreases in OV90 whereas it increases in ES2 and OVCAR3. We conclude that butyric acid induces cell death in all cell lines; and the induction of

\footnotetext{
* Correspondence: fs.fernandasilva.fs@gmail.com

+ Contributed equally

${ }^{1}$ Centro de Estudos de Doenças Crónicas, Faculdade de Ciências Médicas,

Universidade Nova de Lisboa, Lisboa, Portugal

Full list of author information is available at the end of the article
}

apoptosis in OV90 by vorinostat may be through the downregulation of HNF1.

\begin{abstract}
Author details
${ }^{1}$ Centro de Estudos de Doenças Crónicas, Faculdade de Ciências Médicas, Universidade Nova de Lisboa, Lisboa, Portugal. ${ }^{2}$ Centro de Investigação de Patobiologia Molecular, Instituto Português de Oncologia de Lisboa, Lisboa, Portugal. ${ }^{3}$ Serviço de Hematologia- Instituto Português de Oncologia de Lisboa, Lisboa, Portugal. ${ }^{4}$ Serviço de Anatomia Patológica- Instituto Português de Oncologia de Lisboa, Lisboa, Portugal.
\end{abstract}

Published: 24 September 2010

\section{doi:}

Cite this article as: Silva et al: Role of notch pathway and HNF1 in cell death induced by HDACs inhibitors in ovarian cancer cell lines, serous and clear cells. BMC Proceedings 2010 4(Suppl 2):P36.

Submit your next manuscript to BioMed Central and take full advantage of:

- Convenient online submission

- Thorough peer review

- No space constraints or color figure charges

- Immediate publication on acceptance

- Inclusion in PubMled, CAS, Scopus and Google Scholar

- Research which is freely available for redistribution

Submit your manuscript at www.biomedcentral.com/submit 